\title{
The Effectiveness of Early Childhood Inclusive Education Textbook for Students of Inclusive Education Classes in UNIMED
}

\author{
Suri Handayani ${ }^{1}$, Nurmaniah ${ }^{2}$, Srinahyanti $^{3}$, Santa Situmorang $^{4}$ \\ ${ }^{1} P G$ PAUD, FIP, UNIMED, Medan, Indonesia \\ suridamanik@gmail.com
}

\section{Abstract}

The purpose of this research is to describe effectiveness of early childhood inclusive education textbook for students of inclusive education classes in Unimed. The development of this textbook is a type of research and development $(R \& D)$ with the Four-D (4-D) model. This model consists of 4 stages of development, namely Define, Design, Develop, and Disseminate. The sample for this research was students of inclusive education classes in teacher education of early childhood education FIP Unimed, uses purposive sampling technique. The instrument used was an effectiveness sheet filled in by students of inclusive education classes. Data analysis technique is a descriptive analysis in the form of a percentage, while the development of textbook is done through content analysis. Based on the results of student trial, the developed textbook is categorized as very effective with a value of 76.

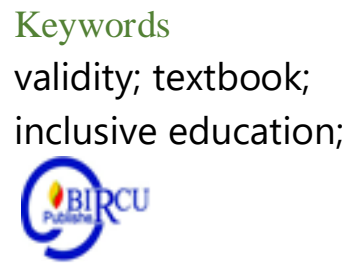

Keywords

validity; textbook

inclusive education;

\section{Introduction}

Early childhood education is a basic and strategic for human beings. There are several factors that underlie the value of early childhood education: First, scientific research results say early childhood is considered the time of golden age. Second, as stated in Law Number 20 of 2003 About the National Education System, early childhood education has become a national commitment. Second, there is a global commitment to Education For All (EFA) which involves six main goals, including focusing directly on those vulnerable to marginalization and separation.

Based on the Law of Ministry of National Education Number 70 of 2009 states that inclusive education is a 'education system that provides opportunities for all students with disabilities and have potential intelligence and/or special talent to attend education or learning in the educational environment along with normal students. This law explains that children with special needs also have the right to be educated in the same way as other normal children. It means that inclusive schools are public schools that serve all children regardless of their physical, mental, cultural, psychological, linguistic or other disabilities, including special needs children.

Inclusive education is performed to fulfill each child's right to proper education. Law No. 20 of 2003 clause 11 paragraph 1 on Government and Regional Government Obligations is that government and regional governments are obliged to provide services and facilities to guarantee the quality of education without discrimination for every children. Children with special needs have the opportunity to study in general classes based on the ability to participate with some changes in school activities. Children with special needs will engage with other normal children in school learning programs. 
Inclusive learning is an educational support system that includes children with special needs in regular schools closer to home, along with other normal children, so that children with special needs are not isolated from their family as much as possible. Inclusive learning is a system of education that is available to all people and adapts to all needs according to individual circumstances.

Law of Ministry of National Education Number 70 of 2009 contains comprehensive guidelines for inclusive education from planning to implementation. One of the important things recorded in the Ministerial Regulation is that regional governments have an obligation to appoint at least one school to conduct inclusive education. Inclusive education, however, is not enough for at least one school in each district / city, but involving many schools in which there are special needs students. This is due to an increase in the number of children with special needs every year.

Increasing children with special needs is not consistent with services for inclusive education. Referring to data from the PSLB Directorate in 2007 , only $24.7 \%$ or 78,689 children from the disabled children population in Indonesia, 318,600 children, attended formal education. This means that up to $65.3 \%$ of children with special needs are still excluded, marginalized and neglected in their right to education. That number is estimated to be much higher in view of the low prevalence rate used, which is $0.7 \%$ of the population and the poor data collection system (Sunaryo, 2009).

The number of children with special needs in Indonesia exceeded 1.6 million children in 2017 based on data from the Central Statistics Agency (BPS). There are 62 districts / towns out of 514 districts / towns across the country that do not yet have a special education. Currently, the number of children with special needs receiving education services has only reached 18 percent, namely around 115,000 children with special needs attending SLB, while children with special needs attending regular schools implementing inclusive schools is about 299,000 children.

Meanwhile, there are still many schools that have faced obstacles. Based on the results of the research (Sunardi 2009, Suyanto 2009) of 12 inclusive schools in Bandung, five issues and problems of inclusive education are awareness and application, school policies, learning processes, teacher condition, and support system. More precisely, of the five groups of issues related to inclusive learning at school level, especially at the level of early childhood education, according to Adnan et al (2012), early childhood educators as second-hand after parents at home, many still have difficulties in identifying and facilitating children with special needs, leading to difficulties for children with special needs accepted at normal school to learn together with other children. Of course this is very contrary to the concept of education for all and the concept of education as early as possible.

Inclusive education is not just a fulfillment of human rights and the rights of children, but is even more important for children's welfare, as inclusive education begins by realizing changes in community beliefs about children with special needs. Kids will feel relaxed, secure, respected, safe, cherished, satisfied and accountable. Inclusion takes place in all children's social environments, in families, peer groups, schools, and other social institutions.

According to Budi S. (2010) inclusive education is carried out based on the spirit of building an inclusive community system, namely social order that respects diversity. So that the inculcation of character will be more appropriate starting early through the implementation of early childhood inclusive education. Inclusive education services every child that has the right to get good education services according to their age and development, 
regardless of the degree, economic condition of the family or their disabilities. It is important for teachers to implement good learning planning so that all children are well served.

The development of teacher competence is absolutely essential for the implementation of inclusive education. According to Suparno (2001), there are substantially two main competency components of inclusive education teachers. First, teacher core competencies including (a) pedagogic, (b) personality, (c) social, and (d) professional (Law of Ministry of National Education Number 16 of 2007). Second, specific competency in early childhood inclusive education which is to have an understanding and ability in terms of; (a) the characteristics and learning needs of children with special needs; (b) learning assessment for children with special needs; (c) creating a friendly learning environment; (d) individualized education programs; and (e) learning evaluation for children with special needs.

The researchers felt the need to develop an early childhood inclusive education textbook for students at FIP Unimed as prospective early childhood teachers based on the background of the issues described.

\section{Methodology}

This research uses research and development $(R \& D)$ model, a research method used to produce certain products and test the effectiveness of that products (Sugiyono, 2010). Textbook development model is a set of procedures that will be carried out sequentially to develop instructional materials. This type of development in this study will use the Four-D (4-D) model suggested by Silvasailam Thiagarajan, Dorothy S. Semmel, and Melvyn I. Semmel (1974). This model consists of 4 stages of development, namely Define, Design, Develop, and Disseminate. This model was chosen because it aims to produce products in the form of early childhood inclusive education textbook for teacher education of early childhood education students.

Defining stage is useful for identifying and defining needs in the textbook and collecting product-related information. There are several steps at this level, including frontend analysis, student analysis, assignment analysis, concept analysis, and instructional goals specification. Then proceed to the design stage after receiving the results from the definition stage. This stage aims to design early childhood inclusive education textbook, which includes content selection and format selection.

The third stage is development stage, with the intention of generating updated early childhood integrated textbook on the basis of expert analysis and student trials. There are two steps at this stage that are the validation of the experts and the testing of the product. After trial and revising the textbook, next stage is the dissemination stage. The purpose of this stage is to disseminate early childhood inclusive education textbook for teacher education of early childhood education students in FIP Unimed.

Validation instrument was used to obtain data on expert evaluations of early childhood inclusive education textbook. The results of this assessment serve as the basis for development of textbook before being trialled. This validation sheet contains appropriateness of content, presentation, graphic, and lingustic. Table 1 below shows the blueprint of instrument.

Table 1. Blueprint of Textbook Validation Instrument

\begin{tabular}{|l|l|l|}
\hline o & \multicolumn{1}{|c|}{ Indicator } & ber of Items \\
\hline \multicolumn{2}{|c|}{ A. Content } & 3 \\
\hline & itability of the material with curriculum & 3 \\
\hline
\end{tabular}




\begin{tabular}{|c|c|}
\hline curacy of the textbook material & 4 \\
\hline rting learning material & 3 \\
\hline date material in textbook & 3 \\
\hline \multicolumn{2}{|l|}{ B. Linguistic } \\
\hline Straightforward & 3 \\
\hline unicative & 2 \\
\hline ical and Interactive & 2 \\
\hline le with the level of student development & 2 \\
\hline g and integrated thought flow & 1 \\
\hline terms, symbols, icons & 2 \\
\hline \multicolumn{2}{|l|}{ C. Presentation } \\
\hline Presentation Techniques & 2 \\
\hline rting Presentation & 4 \\
\hline leteness of Presentation & 3 \\
\hline \multicolumn{2}{|l|}{ D. Graphic } \\
\hline Fonts & 2 \\
\hline y Design & 3 \\
\hline
\end{tabular}

The results of the experts validation are presented in tabular form. Then calculating average score using the formula:

$$
R=\frac{\sum_{i=1}^{n} V_{i}}{n}
$$

$\mathrm{R}=$ the average rating of the validators

$\mathrm{Vi}=$ score of the result of the i-validator assessment

$\mathrm{n}=$ number of validators

Then the average obtained is confirmed with established criteria. How to get these criteria is as follows.

$$
\begin{array}{ll}
76-100 & =\text { very valid } \\
51-75 & =\text { valid } \\
26-50 & =\text { less valid } \\
0-25 & =\text { invalid }
\end{array}
$$

Try out instrument is used to determine the practicality and effectiveness of early childhood inclusive education textbook when used by students. The blueprint of students response sheet shown in Table 2 below.

Table 2 Blueprint of Textbook Practicality Instrument

\begin{tabular}{|l|l|l|}
\hline $\mathbf{0}$ & \multicolumn{1}{|c|}{ Indicator } & $\begin{array}{c}\text { nber of } \\
\text { Items }\end{array}$ \\
\hline \multicolumn{2}{|l|}{ Effectiveness } & 2 \\
\hline \multicolumn{1}{|l|}{ tation organization of learning materials } & 1 \\
\hline & y and enthusiasm for learning material & 2 \\
\hline & 2 \\
\hline & tion in accordance with learning objectives & \\
\hline Creativity in the learning approach &
\end{tabular}




\begin{tabular}{|l|l|l|}
\hline \multicolumn{2}{|l|}{} & 3 \\
\hline S & 3 \\
\hline \multicolumn{2}{|l|}{} \\
\hline Efficiency & 2 \\
\hline \multicolumn{2}{|l|}{} \\
\hline \multicolumn{2}{|l|}{ Appropriateness with curriculum easier for students to obtain information } \\
\hline Attractiveness & 1 \\
\hline$\quad$ Display Design & 4 \\
\hline & 1 \\
\hline & 3 \\
\hline & ster a curious and critical character in students & 2 \\
\hline
\end{tabular}

Data analysis on the practicality of textbook by students was obtained in the following way:

total skor $\quad x \mathbf{1 0 0 \%}$

ideal skor

The results of this quantitative calculation percentage are interpreted, as follows:

\begin{tabular}{|c|c|}
\hline Not practice & $0 \%-25 \%$ \\
\hline Less practice & $26 \%-50 \%$ \\
\hline Practice & $51 \%-75 \%$ \\
\hline Very practice & $76 \%-100 \%$ \\
\hline
\end{tabular}

(Ridwan, in Eza, 2014)

\section{Discussion}

In accordance with the stages in the 4-D Model, the following results of the research have been conducted:

a. Define

This stage has been carried out by interviewing teacher education of early childhood education students and early childhood teachers in Unimed. In addition to interviews, the researchers also made direct observations during the inclusive education classes and discussions with inclusive education lecturers. At this stage the initial analysis, student analysis, task analysis, concept analysis, and analysis of learning objectives are carried out.

1) Initial Analysis

Students were able to understand the management of inclusive classes based on the findings, but they still encounter uncertainty in the introduction of inclusive learning in early childhood education. This is due to the lack of teaching materials or textbooks for early childhood education that provide an outline of the comprehensive framework of learning. Researcher also conducted interviews with teachers of early childhood education to search for basic issues related to teaching materials for inclusive early childhood education. Based on 
the results of the interview, no instructional content has been available to date that explicitly deals with comprehensive early childhood education, so that if there are children with special needs in school the teacher has not been able to facilitate their learning needs. It is therefore necessary to have an inclusive early childhood education textbook that will provide students and teachers with an understanding of the application of inclusive education in early childhood education.

2) User Analysis

At this stage, the researcher made comments on the development of the textbook's prospective users. The target users of this textbook are early childhood teacher education students, particularly FIP UNIMED students. They should understand children's scope and characteristics, not only normal children but also have knowledge about children with special needs. It is also expected that students will be able to understand the learning needs of children with special needs and appropriate handling in inclusive classes will be carried out. Students as teacher candidates must be able to design and do learning by understanding the characteristics of children, especially for children with special needs in an inclusive class together with normal children.

3) Task Analysis

Task analysis is performed to identify the main tasks that students will perform as users of the textbook of early childhood inclusive education. Based on the analysis of the problems at the start and the analysis of textbook users, the researcher formulated the tasks that exist in the development of an inclusive textbook for early childhood education. The assignments are made in the form of tests, evaluation activities and assignments for designing training in inclusive classrooms so that early childhood education educators can recognize and implement inclusive education in early childhood education.

4) Concept Analysis

Concept analysis is performed to determine material content in the textbook of early childhood inclusive education. The definition study was carried out by defining elements of inclusive education and collecting the pieces of learning material in the elements of inclusive education systematically. Referring to Law of Ministry of National Education Number 70 of 2009 concerning Inclusive Education for Students Who Have Disabilities and Have Potential Intelligence and / or Special Talents, there are 15 clauses as a reference for the implementation of inclusive education. Based on these clauses, the researcher compiles and develops material to create early childhood inclusive education textbook. The structure of the learning program at teacher education of early childhood education FIP Unimed is adjusted to the Learning Achievements agreed by representatives of 26 Public Universities and 3 Private Universities held by the Indonesian Teacher Education of Early Childhooh Education Association (APG-PAUD Indonesia) in the Workshop of Teacher Education Of Early Childhood Education Learning Achievement.

Based on the analysis of the concept from Law of Ministry National Education Number 70 of 2009, early childhood inclusive education textbook will include seven materials, namely the basic concepts of inclusive education, children with special needs, curriculum in inclusive class/schools, evaluation of learning in inclusive education, professionals in inclusive education, special services in inclusive education, and the role of families in inclusive education.

5) Analysis of Learning Objectives 
Analysis of learning objectives is carried out to determine indicators of learning achievement based on material analysis and curriculum analysis. Academic competencies at Unimed are formulated into 8 (eight) graduate competencies, namely:

a) Competent to logical and analytical thinking in solving problems

b) Competent to work independently and cooperate with others

c) Competent to communicating ideas and information verbally or in writing

d) Competent to improve science and expertise independently

e) Competent to mastering and using technology

f) Competent to conduct evaluations, analyze data, and create effective solutions to overcome problems

g) Competent to plan and organize activities

h) Competent to adapt to the work environment and society

In developing early childhood inclusive education textbook, researcher use and develop competencies $1,2,3,4,6$, and 7

b. Design

After getting the results from the defining stage, then proceed to the design stage. This design phase aims to design early childhood inclusive education textbook that can be used in learning program in the teacher education of early childhood education FIP Unimed. This design phase includes:

1) Selection of Teaching Content

Based on the analysis of concepts and learning objectives that have been carried out in the previous defining stage, then in the development of early childhood inclusive education textbook, teaching content consists of seven parts. The first part with the topic of the basic concepts of inclusive education contains material about the background of inclusive education, the principles of inclusive education, and the foundation of inclusive education. The second part about children with special needs discusses the characteristics of children with special needs and children learning needs according to the child's disability. The third part is the curriculum in the inclusive classroom/school which contains material on modification, adaptation, and design of learning in the inclusive classroom.

The fourth part is the evaluation of learning outcomes in inclusive education which is concerned with accommodation and evaluation methods for students with special needs. The fifth part, namely professional staff in inclusive education, contains material on general education teachers, special education teachers, and other related service providers/specialists. The sixth part is about the types of special services in inclusive education. The seventh part contains topics about the role of the family in inclusive education, discusses the forms of parent and family involvement in inclusive education.

2) Format Selection

Teaching materials developed are early childhood inclusive education textbook whose target users are teacher education of early childhood education students. This textbook is made on paper with a size of B5 (JIS) $18.2 \mathrm{~cm}$ x $25.7 \mathrm{~cm}$, in accordance with international standards book size. Paper orientation is portrait. The font used in teaching materials also follows the book's international standards, namely Bookman Old Style with size 11 for content writing, and size 26 for title.

The front cover is designed with a light blue background and there are images related to inclusive education. According to Gross (2018) the color blue gives the impression of communicative, calm, and is a universal color that is often chosen. Even some world-famous trademarks use blue to show reliability, authority and quality of harmony. Images relating to 
inclusive education are made on the front cover to strengthen the content. The components in the front cover are the title of teaching material and the identity of the author.

The beginning of each chapter contains the title and learning objectives related to the material in the chapter. This is intended so that students know what competencies are expected after studying the chapter. In the contents of each chapter, there are pictures / charts I diagrams to make it easier for students to understand the material. At the end of each chapter, there are evaluation, summary, and bibliography.

c. Development Stage

This development phase aims to produce early childhood inclusive education textbook that have been revised based on experts validation. This textbook was validated by two validators, consisted of experts in the field of early childhood education and experts in the field of lingustic. The results of the validity test of teaching materials by the validator are shown in Table 3 below.

Table 3. Test Results of Textbook Validity

\begin{tabular}{|c|l|c|l|}
\hline. & \multicolumn{1}{|c|}{ Modul Criteria } & rcentage & Category \\
\hline & At eligibility & 86,5 & Very valid \\
\hline & tation Eligibility & 83,3 & Very valid \\
\hline & ic & 90 & Very valid \\
\hline & stic Average & 85,4 & Very valid \\
\hline & \multicolumn{2}{|c|}{86,3} & Very valid \\
\hline
\end{tabular}

After expert validation, a limited field trial is then conducted to determine the practicality and effectiveness of the use of early childhood inclusive education textbook in inclusive education classes. The practicality is a practical standard, easy, and cheap a teaching material to use. (Eza, 2014). Meanwhile, the effectiveness is the achievement of the expected understanding of inclusive education for early childhood.

The practicality test of textbook is done by filling out a questionnaire by students, after using the textbook in inclusive education classes. The results of the questionnaire analysis of textbook practicality is $76 \%$ with a very practical category. For more details, see Table 4 below.

Table 4. Results of questionnaire practicality of teaching materials by students

\begin{tabular}{|c|l|c|c|}
\hline No & \multicolumn{1}{|c|}{ Modul Criteria } & Percentage & Category \\
\hline 1. & Effectiveness & $75,2 \%$ & Very effective \\
\hline 2. & Creativity & $74,1 \%$ & Creative \\
\hline 3. & Efficiency & $79 \%$ & Very efficient \\
\hline 4. & Attractiveness & $75,5 \%$ & Very attractive \\
\hline \multicolumn{2}{r|r}{ Average } & $76 \%$ & Very practice \\
\hline
\end{tabular}

From the results of the questionnaire analysis above, it can be said that these textbook are categorized as very practical with a percentage of practicality of $76 \%$. This means that the developed teaching materials already meet the practical requirements that are effective, creative, efficient, and attractive to be used as the main material in inclusive education learning. 
Indicators that determine the practicality of textbook in terms of effectiveness are organizing the presentation of learning materials, mastery and enthusiasm for learning materials, evaluation in accordance with learning objectives, and flexibility in learning approaches. In terms of creativity, aspects that become indicators are related to the person (student), the learning process that stimulates creativity, and the resulting textbook products. The indicator in terms of efficiency is the suitability of learning with curriculum and can facilitate students in obtaining information. Finally, indicators of attractiveness are related to the display design, fonts, images, and can foster a curious and critical character in students.

Students responded that early childhood inclusive educational textbook made it easier for them in the learning process of inclusive education course. This teaching material helps them build mindsets and understandings about inclusive education practices for early childhood, especially handling of children with special needs. Evaluations and activities in this textbook increasing students' critical and creative thinking skills to design learning that can facilitate the learning needs of all children, both normal children and children with special needs.

\section{Conclusion}

Early childhood inclusive education textbook is declared to be very valid (validation value 86.3) and is suitable use for teacher education of early childhood education students (practicality value 76). For future research, it is better to expand and deepen the content of early childhood inclusive education textbook, especially about inclusive classroom curriculum.

\section{References}

Berjenjang: Diklat Dasar. Direktorat Pembinaan Pendidik Dan Tenaga Kependidikan PAUD NI Direktorat Jenderal PAUD NI Kementerian Pendidikan Dan Kebudayaan.

American Psychiatric Association.1994. Diagnotic and Statistical Manual of Mental Disorders. 4th ed. Washsington DC: APA

Departemen Pendidikan Nasional. 2003. Undang- Undang Republik Indonesia Nomor 20 Tahun 2003 tentang Sistem Pendidikan Nasional. Jakarta: Depdiknas.

Departemen Pendidikan Nasional. 2009. Undang- Undang Republik Indonesia Nomor 70 Tahun 2009 tentang Pendidikan Inklusif Bagi Peserta Didik Yang Memiliki Kelainan Dan Memiliki Potensi Kecerdasan Dan/Atau Bakat Istimewa. Jakarta: Depdiknas.

Depdiknas, Dirjen Mandikdasmen, dan Direktorat P L B. (2007). Pedoman Umum Penyelenggaraan Pendidikan Inklusif. Jakarta: Depdiknas.

Elliot, S. 2008. The Effect of Teachers' Attitude Toward Inclusion on the Practice and Success Levels of Children with and without Disabilities in Physical Education. International Journal of Special Education

Elisa, S \& Wrastari, AT. 2013. Sikap Guru Terhadap Pendidikan Inklusi Ditinjau Dari Faktor Pembentuk Sikap. Fakultas Psikologi Universitas Airlangga Surabaya: Jurnal Psikologi Perkembangan Dan PendidikanVol. 2, No. 01, Februari 2013

Fanu, J.L. 2006. Deteksi Dini Masalah-Masalah Psikologi Anak. Yogyakarta: Think Florian, Leni 2008. Special or Inclusive Education: Future Trends. Dalam British Journal of Special Education. 